\title{
THE THEORY OF VITAL ENERGY ACCORDING TO WELL-KNOWN MODERN ARMENIAN WRITER
}

\begin{abstract}
Among all nations representing ancient civilizations, beginning with antic times wise thinkers have examined issues of interrelations between life and death, macrocosm and microcosm, soul and body, and not only from the viewpoint of their own person, but also their nation and even the entire humanity.

Razmik Davoyan has created his own theory, having practical significance, which has a unique goal, i.e. to help the modern human being not only in Armenia, but all over the world to solve more easily difficulties of human life and to make the real life more beautiful by correct use of the vital energy.
\end{abstract}

Keyswords: vital energy, Davoyan, philosophy, upbringing, education, work, the Bible, Creator, bad, good.

Among all nations representing ancient civilizations, beginning with antic times wise thinkers examined issues of interrelations between life and death, macrocosm and microcosm, soul and body, and not only from the viewpoint of their person, but also their nation and even the entire humanity.

It suffices to observe the example of Armenian literature. Movses Khorenatsi, Father of the Armenian historiography, discusses this issue in the Lamentation which closes his History of Armenia (Khorenatsi, 1981, pp. 453-455).

Grigor Narekatsi turns to these issues in his entire genius masterpiece The Book of Lamentation and especially in its $56^{\text {th }}$ episode (Narekatsi, 2007, pp. 268-271). Hovhannes Tumanian in his Quatrains (Tumanian, 1990, pp. 47-57) and Avetik Isahakian in his poem
Abu-Lala Mahari (Isahakian, 1974, p. 61) discuss these issues as well. They are strongly tied with the system of ontology and those problems of vital energy which studies Razmik Davoyan in his new and topical book The Role and Significance of Vital Energy in the System of Ontology.

Davoyan cites that list of directly used literature which includes the Book of Genesis of the Bible Old Testament, the book The Mythology Worshipping Hellas by Mikael Bartikian, the work Zen on The Art of Archery by Eugen Herrigel, as well as works by Thomas Elliot, Artak Movsisyan, Albert Camus, Boileau and Confucius. This is a small list of authors from many countries. I am sure that his theory of vital energy was formed during long years, after reading different books and, which is the most important, out of his own life expe- 
rience. By the way, he gives the enumeration of different philosophers and diverse names of philosopher-writers, from which there is no quotation, but they are surely known to the author (Davoyan, 2016, p. 16).

Razmik Davoyan created his theory of practical importance which goal is only one: to help nowadays people not only in Armenia, but all over the world to make easier the life difficulties and to make real life more beautiful. His theory is ending with the following conclusion: "The Creator is Himself universal love and peace. He is spreading these adamant crystals of love over the world and, growing up they will cover the world with love" (Davoyan, 2016, p. 204).

In all times and in all branches of science there is the reality of hypothesis. They also exist nowadays, sometimes in exaggerated quantities. Razmik Davoyan either has in his quite interesting book a series of hypotheses. He even proposes the following: "It is worth to create now with full right a science, side by side with other sciences, and to call it hypothesiology, the activity field of which will have no limits (Davoyan, 2016, p. 19).

A huge literature was created about the contradiction between good and evil, God and the devil. Of course, it is radically discussed in the Bible. Davoyan believes in some facts of the Old Testament which are refuted by the science. According to him, the fact of many hundred years life of first human beings, as mentioned in the Book of Genesis, was real. Those long years were reduced because of human sins. In his work Davoyan repeats several times the idea of little Johnny, the unforgettable personage of William Saroyan's play, saying that somewhere something is wrong... (Davoyan, 2016, p. 27). Here is this passage:
Johnny: Where the hell do we think we're going, $\mathrm{Pa}$ ?

Johnny's Father: Never mind, Johnny. You just follow me.

Johnny: I'm not mentioning any names, $\mathrm{Pa}$, something's wrong somewhere

(Saroyan, 1987, p. 67).

A passage of R. Davoyan's book concerns globalization and open society. Globalization is a modern notion, but its real father can be considered Alexander of Macedonia, thanks to whom Hellenism made his apparition in the word.

For the sake of the common benefit of the humanity Davoyan refuses globalization which is based on the economic profit and the military domination of a few nations. He also studies the issues of interrelations between society, powerful individuality and crowd.

According to Davoyan, the force of evil can be diminished as far as possible by the means of vital energy. While he remarks about the great Aristotle: “... Aristotle's doctrine shows that the suffering and the evil cannot entirely disappear from the world where human beings are living and acting, as the 'substance' is insurmountable; the human being is mortal, he is condemned to death, and the level of perfection he can reach is always relative. Platonicians and Christian philosophers recognize, as well as Aristotle, the inevitability of sufferings and evil on the earth" (Aristotle, 1984, p. 35). This quotation is made from the foreword written by D. Kessidi for the book Ethical works by Aristotle.

David the Invincible, who calls philosophy a science about divine and human realities (David the Invincible, 1980, p. 67), thinks as follows: he considers philosophy according to Plato as similarity to God (David the Invin- 
cible, p. 80) according to human capacities.

According to Razmik Davoyan the human being can increase his possibilities if he sets his hopes on vital energy.

He often repeats the words of Leonardo da Vinci addressed to humanity: "Open your eyes".

The theory of vital energy is discussed from the viewpoint of Jesus Christ's doctrine, according to which the human life does not end in its known and visible part, but continues after it as well and it is necessary to take care of it. Plato, who confirms the eternity of the soul, writes in his Phaedo: "In fact, there is either reanimation or birth of living beings from dead and existence of the souls of dead people" (Plato, 2006, p. 81).

The Pythagoras philosophy, which is older than the doctrine of Plato, warns its adepts that every day when anyone comes home he must check himself for the sake of his future and ask himself: "Have I sin (today)? What have I done? What I had to do and did not?" (Pythagoras, 2004, p. 333).

In the extra-goal of regulating the behavior of human being in visible life according to divine commands, Davoyan gives a great importance to the educational system which must be reconstructed according to his demands, "in order to get a perspective of realizing the human ideal of 'perfect man', but not an unrealizable tragedy" (Davoyan, 2016, p. 143).

Davoyan speaks separately about the forms and kinds of manifestation of vital energy, the necessity of its preservation and its means. In general lines he divides vital energy into following kinds: a) The vital energy transmitting itself by human communication or human vital energy.

b) The vital energy transmitting itself by communication between man and nature.

c) The vital energy transmitting itself by communication between man and animals, or vital energy of the animal world.

d) The Vital energy of literature and arts.

e) The energy of thought.

f) The energy of passion. (Davoyan, 2016, p. 96).

Davoyan notes righteously that there are vampires of vital energy in the human society. In his works he has numerous new commentaries of Biblical commentaries, through which one will make much easier those difficult moments of human life which are created by men themselves, unjustly steeling the vital energy of others.

According to Davoyan, the formula "Life is struggle" coming from old life must be changed into the formula "Life is work and felicity" (Davoyan, 2016, p. 59).

The demand of the author to save man's time is sounding more than topical. Even today the time of everybody is stolen by ours, days and months and sometimes even by years. They have to wait in the antechambers of bosses and State functionaries.

The real duration of human life is reduced by fear, panic, distressing hours of waiting, dignity humiliations, intrigues made out of personal interest, stolen purse, lost watch or wrong weighing of food.

Such phenomena which take away vital energy may be prevented by reorganizing the activities of the educational system, which 
will allow reaching wanted results. This is the main basis of the writer in the development of his theory.

With his practical theory of vital energy Davoyan seems to realize the following demand of the great German philosopher Emmanuel Kant: "We are a priori determined by reason to contribute by all means to the welfare in the world which consists in the union of the greatest welfare of reasonable beings in the world with the highest condition of good in them, i.e. [union] of everybody's happiness with the most law-governed morality" (Kant, 1999, p. 1335).

The concern of Razmik Davoyan is for healthy humanity, a goal to be reached by the theory he has created, basing himself on progressive thinkers of many centuries and the Bible. Thus, he also, as Solomon the Wise, the author of the Ecclesiastes, can say as epilogue: "The preacher sought to find out acceptable words; and that which was written was upright, even words of truth" (Ecclesiastes, 10).

\section{REFERENCES}

Aristote. (1984). Sochineniya v 4 tomakh (Works in Four Volumes, in Russian), Vol. 4. Moscow: Nauka.

Bible. (2015). Hin \& nor ktakaranner (The Old and New Testaments, in Armenian). Mother See of Holy Echmiadzin. David the Invincible. (1980). Erker (Works, in Armenian). Yerevan: Sovetakan grogh.
Davoyan, R. (2016). Goyabanakan hamakarg, Kensakan e'nergiayi dern $u$ nshanakut'yuny' goyabanakan hamakargum (The Role and Importance of Vital Energy in the Ontological System, in Armenian). Yerevan: Munetik.

Isahakian, A. (1974). Erkeri jhoghovac'u vec hatorov (Works in Six Volumes, in Armenian), Vol. II. Yerevan: Hayastan hratarakchut'yun.

Kant, E. (1999). Osnovy metafiziki nravstvennosti (Principles of the Morality Metaphysics, in Russian). Moscow: Mysl'.

Khorantsi, M. (1981). Hayoc patmut'yun (History of Armenia, in Armenian). Yerevan: EPH hratarakchut'yun.

Narekatsi, G. (1979). Matean voghbergut'yan (Book of Lamentation, in Armenian). Yerevan: Sovetakan grogh.

Pithagoras. (2004). Zolotoi kanon, Figury ezoteriki (The Golden Law, Figures of Esotericism, in Russian). Moscow: Eksmo.

Plato. (2008). Erker chors hatorov (Works in Four Volumes, in Armenian), Vol.1. Yerevan: Sargis Khachenc-Print'info.

Saroyan, W. (1987). Eight Plays. Yerevan: Luys.

Tumanian, H. (1990). Erkeri liakatar jhoghovac'u tas hatorov (Complete Works in Ten Volumes in Armenian), Vol. II. Yerevan: Hayastani GA hratarakchut'yun. 